\title{
A New Approach for Proper Reporting of Pension Benefit Obligations in the Financial Statements of "Old Funds" for Professionals
}

\author{
Carla Morrone ${ }^{1}$, Maria Teresa Bianchi ${ }^{2}$ \& Anna Attias ${ }^{2}$ \\ ${ }^{1}$ University of Naples "Parthenope", Italy \\ ${ }^{2}$ Sapienza, University of Rome, Italy \\ Correspondence: Maria Teresa Bianchi, Department of "Diritto ed Economia delle attività produttive", Sapienza \\ University of Rome, Via del Castro Laurenziano n. 9, 00161, Rome, Italy.
}

\author{
Received: June 30, 2020 \\ doi:10.5539/ibr.v13n8p117 \\ Accepted: July 22, $2020 \quad$ Online Published: July 23, 2020 \\ URL: https://doi.org/10.5539/ibr.v13n8p117
}

\begin{abstract}
In this paper, we focus on the disclosure of pension liabilities for entities referred to in Italian Legislative Decree 30 June 1994 no. 509 (also called "old funds" for professionals), which is crucial for a suitable communication. After illustrating the limits of current statutory financial statements' in relation to the information they provide on pension benefit obligations, we propose three potential solutions to bridge the gap. Each of these proposals helps ensure the completeness and clarity of financial reporting and improves upon the informational capacity and quality of disclosure. In our opinion, one of these approaches, in particular, would be preferred because of its ease of adoption. Indeed, the disclosure in the explanatory notes allows for the quantification of pension benefit obligations, and hence a more proper evaluation of entities in the medium/long- term, with no impact on annual economic-financial results as reported in the balance sheet and the income statement.
\end{abstract}

Keywords: professionals' old pension funds, pension benefit obligations, complete disclosure, future pension liabilities

\section{Introduction}

As evidenced by Chiacchio and Tagliapietra (2018) the Italian debate on the pension system predominantly focuses on short-term aspects, neglecting relevant longer-term fundamentals. In this paper, we will highlight how this short-term focus also characterizes the statutory financial statements of entities governed by Legislative Decree no. 509/94.

The first pillar of the Italian social security system for freelance professionals is entrusted with two main groups of privatized entities as detailed in the II Report 2015 (Technical Scientific Committee of Itinerari Previdenziali, 2015): pension schemes ex Legislative Decree n. 509/94, the so-called "old funds" and pension schemes $e x$ Legislative Decree n. 103/96, called "new funds".

The first group is composed of the following entities: ENPACL (labor consultants), ENPAV (veterinary doctors), ENPAF (pharmacists), CNPAF (lawyers), INARCASSA (engineers and architects), CIPAG (surveyors and evaluators), CNPR (accountants), CNPACD (chartered accountants), CNN (notary publics), ENPAM (doctors) and INPGI (journalists).

The second group is composed of the following entities: ENPAB (biologists), ENPAIA (agricultural experts and land surveyors), EPAP (agronomists and forestry experts, actuaries, chemists and geologists), EPPI (industrial engineers and graduates), ENPAP (psychologists), ENPAPI (nurses) and INPGI 2 (journalists, separate account).

The aim of this paper is to analyze how "old funds" report pension benefit obligations (PBOs) (Note 1) in their financial statements, and to further propose potential approaches to better represent them. Within this scope, and after having pointed out that the PBOs are currently not properly reported in either the balance sheet or in the explanatory notes, our research question is "how can financial statements be improved with specific regard to future pensions that will become due in consideration of contributions paid and recorded in the asset section?".

This paper is organized as follows. Section 2 describes the two main documents of "old funds" reporting, highlighting the lack of PBOs in the statutory financial statements. Section 3 explains why this absence represents an issue. In Section 4 we propose possible solutions to proper disclosure, which are then further discussed in the last section. 


\section{Theory}

\subsection{Pension Calculation}

Pensions can be calculated with different approaches which could have a significant impact on the pension computation (Attias, Arezzo, Pianese, \& Varga, 2016). In particular, we distinguish between two different methods for the calculation: the income-based system, the so-called Defined Benefits (DB), that evaluates pensions considering the average of an individual's "last" income (Note 2); and the contribution-based system, the so-called Defined Contributions (DC), that evaluates pensions considering contributions paid by each professional over their whole working life (Kalyta \& Magnan, 2008). In other words, by using the latter method pensions are estimated referring to contributions provided during an individual's entire professional life, rather than just their "last" income (Kemp \& Patel, 2012), which shows a sharp decline in gross substitution rate (SR) (Note 3). Using this method, the pension is determined by multiplying the amount of contributions paid over an individual's whole professional life (calculated applying the benefit growth rate (Note 4)) by an age-related transformation coefficient, which reflects the life expectancy at retirement, without a sex distinction, and consequently the expected number of annual pension payments (Franco, 2001).

\subsection{Pension Funds Reporting}

The primary documents which make up privatized pension schemes' reporting are the actuarial statements (also called the "technical budget") and the statutory financial statements.

The actuarial statements are drafted, at least every three years (Note 5), based on forecast data (Note 6) while the statutory financial statements are drawn up annually with final data.

The actuarial statements detail information regarding the applicable legislation in force at the date of drafting, on the financial management system, on demographic, economic and financial data, on the technical bases adopted and on methodology used. As stated by the Ministerial Decree November 29, 2007, technical budget should develop projections of data with reference to the time lapse of 50 years.

The most common methodologies used to develop technical budgets are MAGIS (Coppini, 1979; Tomassetti, 1973), Monte Carlo simulation and Exact Individual Trajectories Method (EIT) (Angrisani \& Attias, 2004). Monte Carlo is a stochastic simulation to model the probabilities for different trajectories founded on the Large Numbers Law. In the MAGIS version (the method of management years on an individual basis and with a draw), the elementary probabilities, referring to each individual, are used as weights of random extraction. In this case, trajectories are out of control due to the polynomial aspect which considers all "possible fates". The EIT is set up on an axiomatic individual basis which takes into account, for each fund's member, the set of all feasible trajectories, that is, all possible life events. Most notable, EIT, starting from the vital cycle of when the professional enrolled in the fund, identifies only the feasible trajectories (that is, the history of each professional is non polynomial) and so trajectories are under control.

Technical budgets allow for the assessment of both the sustainability of the system, from a medium/long-term perspective, and the intergenerational equity and solidarity (Guardiancich \& Natali, 2018), which is given by the stable and fair ratio between contributions and benefits paid. With regard to sustainability, it is useful to highlight that the financial crisis has further emphasized the need for performance measures which are able to determine the ability to effectively provide income replacement at retirement age (Hinz, Heinz, Antolin, \& Yermo, 2010). Indeed, the European Union also focuses on the sustainability of pensions in several documents (European Commission, 2010, 2018a, 2018b; European Economic and Social Committee, 2010), particularly in the 2010 Green Paper where it states "An adequate and sustainable retirement income for EU citizens now and in the future is a priority for the European Union. Achieving these objectives in an ageing Europe is a major challenge. Most Member States have sought to prepare for this through pension reforms." Adequacy and sustainability need to be addressed jointly (Alonso-García, Boado-Penas, \& Devolder, 2018) with the aim of solidarity and equity between and within generations. In this context demography plays a very important role.

During the period between 1946 and 1964 the so-called "baby boom" phenomenon occurred (Mazzola et al., 2016). People born during this period represented a large number of professional funds' members in the ' 90 s. The mass of these professionals will retire around 2025/2030 with the problem arising that beneath this population there is a "hole" from the enormous decrease in births since the "70s. This demographic tsunami phenomenon will create an unbalanced relationship between active professionals and retired ones, the immediate consequence of which will be asset erosion. Therefore, sustainability has to be based on the real performance of the variables that have the inherent ability to determine sustainability itself (Angrisani \& Di Nella, 2011), and in this sense the financial statements are crucial. Indeed, the actuarial budgets report the projections of the possible evolution in terms of 
inputs (mainly contributions and returns) and outputs (mainly pensions and operating expenses) in consideration of demographic, economic and financial technical bases esteemed by the editor; these projections are not the estimation of the pensions liabilities of privatized entities at the date of the statements (Geroldi, 2014).

The statutory financial statements are administrative-accounting documents used to inform all categories of stakeholders about the economic, financial and asset situation of an entity (Amaduzzi, 1970; Bastia, 1989; Capaldo, 1998).

The legislator has, in fact, ordered that the financial statements must be drafted with clarity, truth and correctness: the principles of the general drafting clause contained in article 2423 of the Civil Code. The right to information of members and third parties is, first of all, the right to economically true information, technically correct and effectively intelligible and therefore clear and this right is guaranteed by art. 2423 of the Italian Civil Code (L. A. Bianchi, 2013). The financial statements are legitimately prepared, therefore the shareholders' resolution that approved them is valid only in the presence of clarity, truth and correctness. This means that none of these principles can be renounced in order to be able to speak fully of a legitimate balance sheet (M. T. Bianchi, 2001).

These can be drafted according to different standards (Capodaglio, Santi, \& Tozzi, 2011; Quagli, 2017). In Italy, the financial statements of "old funds" must be compliant with rules of Civil Code, suitably adapted - lacking regulation - to that typical of privatized social security entities (M. T. Bianchi, Nardecchia, \& Tancioni, 2014). In particular, article 2423 c.c., as modified by the Legislative Decree no. 139/2015, states that financial statements are made up of a balance sheet, income statement, statement of cash flows and explanatory notes to the financial statements. This article also specifies that additional disclosures must be provided if these are necessary in order to give a true and fair representation of an entity's affairs (PwC, 2017). According to us, these disclosures are necessary, and additional information concerning the PBO must be reported in order to provide a true and fair representation (Marcello \& Lucido, 2019). Indeed, as argued by Reiter and Omer (1992), in the area of pension accounting, [...] the accounting choices play a major role in distributional decisions, particularly the distribution of wealth between shareholders and employees and it could cause the deferral of pension funding to future periods (Chaney, Copley, \& Stone, 2002). Even if financial statements are frequently considered to be neutral, objective and consequently trustworthy, in actuality this is not always the case. This is especially notable for pension funds which have specific measurement issues (Schipper \& Trombetta, 2010), such as with the calculation of future pensions. The implication for accounting standard-setting bodies is that both the pension plan assets and pension obligations should be disclosed to facilitate users in making predictions about changes in the economic liability (Selling \& Stickney, 1986).

\subsection{Analysis of Statutory Financial Statements of Old Funds}

In this paper, we analyzed financial statements of all the "old funds" that, in compliance with the first article of the Legislative Decree no. 509/94, register at least a reserve equal to 5 annuities of pensions in the equity section and do not report any additional disclosure about PBOs in either the balance sheet or in the explanatory notes. The absence of all PBOs significantly impacts the completeness (M. T. Bianchi, 2001) and the quality of disclosure (Beretta \& Bozzolan, 2008). Indeed, to be exhaustive and to satisfy stakeholders' needs, communication should refer to both current and prospective performances (Quagli, 2004). The guiding thread of our logical reasoning is exactly from this perspective.

In Table 1 we recap the amount of contributions paid in 2018, the recorded PBOs and the number of members in the same year for each fund.

Table 1. Data of old pension funds (source: financial statements 2018)

\begin{tabular}{llll}
\hline Old funds & $\begin{array}{l}\text { Contributions 2018 } \\
\text { (in millions) }\end{array}$ & Recorded PBOs & Members 2018 \\
\hline ENPACL (Labor consultants) & $€ 200$ & none & 25469 \\
\hline ENPAV (Veterinary doctors) & $€ 117$ & none & 29252 \\
\hline ENPAF (Pharmacists) & $€ 271$ & none & 95656 \\
\hline CNPAF (Lawyers) & $€ 1632$ & none & 246945 \\
\hline INARCASSA (Engineers and Architects) & $€ 1080$ & none & 168851 \\
\hline CIPAG (Surveyors and Evaluators) & $€ 525$ & none & 84202 \\
\hline CNPR (Accountants) & $€ 330$ & none & 28776 \\
\hline CNPADC (Chartered Accountants) & $€ 839$ & none & 68552 \\
\hline CNN (Notaries) & $€ 295$ & none & 6270 \\
\hline ENPAM (Doctors) & $€ 2933$ & none & 645893 \\
\hline
\end{tabular}




\section{Results and Discussion}

\subsection{Results}

The analysis pointed out that PBOs are not accounted for either in the financial statements or in the technical budget, undermining their disclosure (Andrietti, 1995; Morrone \& Angrisani, in press), which is critical for multiple stakeholders and may impact sustainability evaluation (Angrisani, 2008; Angrisani \& Di Palo, 2019).

That said, it is then necessary to define a proper accounting principle that is able to take into consideration the contracted retirement promises (Olivieri, Fersini, Melisi, \& Brusco, 2015; Rosa, 2012) by prevailing the economic substance over legal form as regulated by the principle introduced by article 2423 bis of the Civil Code as amended by article 6, paragraph 3, letter b) of Legislative Decree no. 139/2015. Indeed, pensions not yet due to members because of the absence of the event that implies payment, will nevertheless eventually become due considering the peculiarity of the privatized entities. It is useful to specify that even though the members of the funds are not properly a third party of the entity, defining with them a relationship of a substantially participatory nature, we postulate the position of these certainly characterized by legal protection (Castellino, 1985). The merit for this kind of disclosure is affirmed by the "new funds" that already report this data in their balance sheets. As an example, the balance sheet of ENPAPI as at $31^{\text {st }}$ December 2017 reports obligations for future pensions in dedicated funds ("B4a Social Security Fund": $€ 606164$ 060, "B4b Pension Fund": $€ 48461$ 927 and "B4e IVS Fund (invalidity, old age, survivors), separate account": $€ 40467889$ ).

\subsection{Our Proposals}

Based on the analysis performed, we think that a new and specific accounting principle must be designed in order to ensure proper representation of PBOs in the financial statements of "old funds" (Vermeer, Styles, \& Patton, 2012). Hence, we propose the following possible solutions to make the financial statements clearer and more informative:

1) registration of a reserve that refers not only to the next 5 years, but which also takes into account a longer time horizon;

2) creation of a fund that effectively integrates the five-year reserve, recording the future obligations;

3) use of the explanatory notes, rather than the quantification of pension benefit obligations in the balance sheet, to create a special section in which to insert the "potential" debt and, therefore, the operational risk (Kaifala, C. Paisey, \& N.J. Paisey, 2019) over a wider period than only 5 years. This would create a link between the financial statements and technical budgets, positively impacting the financial statement information.

The first two solutions have a particularly forceful impact because they oblige entities to represent the pension benefit obligations of the following annuities in each financial year (Chaney et al., 2002). The third solution is able to offer a complete disclosure, but appears less "invasive" since it does not directly affect an entity's annual economic-financial results (Giunta \& Pisani, 2020).

Therefore, by choosing the third solution it can be assumed that in the explanatory notes the pension benefit obligations of a privatized entity towards its members in the long-term (at least, 20 years) must be indicated, thus highlighting a relevant information for stakeholders.

Such a scheme therefore allows for the construction of a more comprehensive disclosure able to evaluate the sustainability, by creating a proper logical interconnection between the purposes of the financial statements and the technical budgets.

\section{Conclusion and Possible Future Researches}

At present, the statutory financial statements of old funds do not present a complete disclosure of pension benefit obligations. Furthermore, the information that can be deduced from the technical budget is constructed with criteria other than those from general accounting and, therefore, does not possess the same informational value. It is essential that the reader of the financial statements has information on the pension debt of the Fund, otherwise the general financial statement drafting clause is not respected due to the lack of clarity.

This demonstrates the need for a different method of presentation.

Utilization of merely quantitative hypotheses could generate complex effects on financial statement results. Conversely, the quantification of pension benefit obligations in the explanatory notes informs the reader without altering results, enabling the analysis of an entity's sustainability, while still providing all the values on the possible evolution in the long run.

A limitation of this paper refers to the peculiarities concerning Italian "old funds" for professionals that are not 
easily comparable to other pension funds around the world. Moreover, this analysis does not stress the actuarial issues related to the quantification of pension benefit obligations that could be considered in further researches. Another interesting future study linked to the problem highlighted in this paper concerns the specific risk of the funds represented by the possibility for members to ask back their paid contributions. This latter, indeed, has a significant impact on one side, on the accuracy, completeness and clarity of financial statements and, on the other side, on the pension system's sustainability evaluation that is relevant also for European policies (European Commission, 2010, 2018a, 2018b; European Economic and Social Committee, 2010).

\section{References}

Alonso-García, J., Boado-Penas, M. D. C., \& Devolder, P. (2018). Adequacy, fairness and sustainability of pay-as-you-go-pension-systems: defined benefit versus defined contribution. European Journal of Finance, 24, 1100-1122. https://doi.org/10.1080/1351847X.2017.1399429

Amaduzzi, A. (1970). Tematica sui bilanci delle Società azionarie. Rome, K libreria editrice.

Andrietti, V. (1995). Una stima del debito previdenziale maturato dai principali fondi pensionistici Inps al 31 dicembre 1991. Rivista Internazionale di Scienze Sociali, 103, 699-742.

Angrisani, M. (2008). The logical sustainability of the pension system. Pure Mathematics and Applications, 19(1), 67-81.

Angrisani, M., \& Attias, A. (2004). A mathematical model for the management of an Invalidity Old Age Survivor Pension Fund: The Exact Individual Trajectories Method. Pure Mathematics and Applications, 15(1), 1-15.

Angrisani, M., \& Di Nella, G. (2011). Casse professionali, patrimoni e sostenibilità. Retrieved from http://www.logicaprevidenziale.it/joomla/index.php?option=com_content $\&$ view=article\&id=82:casse-profe ssionali-patrimoni-e-sostenibilita\&catid=38:editoriali-dicembre-2011\&Itemid=2

Angrisani, M., \& Di Palo, C. (2019). The Logical Sustainability Theory for pension systems: the discrete-time model in a stochastic framework under variable mortality. Pure Mathematics and Applications, 28(1), 1-25. https://doi.org/10.1515/puma-2015-0029

Attias, A., Arezzo, M. F., Pianese, A., \& Varga, Z. (2016). A comparison of two legislative approaches to the pay-as-you-go pension system in terms of adequacy. The Italian case. Insurance: Mathematics and Economics, 68, 203-211. https://doi.org/10.1016/j.insmatheco.2016.03.010

Bastia, P. (1989). Il bilancio d'impresa. Formazione e interpretazione. Bologna, CLUEB.

Beretta, S., \& Bozzolan, S. (2008). Quality versus quantity: the case of forward-looking disclosure. Journal of Accounting, Auditing and Finance, 23, 333-375. https://doi.org/10.1177/0148558X0802300304

Bianchi, L. A. (2013). Bilanci, operazioni straordinarie e governo dell'impresa: Casi e questioni di diritto societario. Milan, EGEA.

Bianchi, M. T. (2001). Il principio della chiarezza in una recente sentenza della Corte di Cassazione. Rivista Italiana di ragioneria e di economia aziendale, 5-6, 249-255.

Bianchi, M. T., Nardecchia, A., \& Tancioni, F. M. (2014). Pension Fund's Corporate and Economic Profiles. International Business Research, 7(11), 181-189. https://doi.org/10.5539/ibr.v7n11p181

Capaldo, P. (1998). Reddito, capitale e bilancio di esercizio. Una introduzione. Milan, Giuffrè.

Capodaglio, G., Santi, M., \& Tozzi, I. (2011). The introduction of international accounting standards in the italian small and medium sized entities. Economic Research, 24(2), 126-136 https://doi.org/10.1080/1331677X.2011.11517461

Castellino, O. (1985). Is there a second public debt (larger than the first)?. Moneta e Credito, 38(149), 21-30.

Chaney, B. A., Copley, P. A., \& Stone, M. S. (2002). The effect of fiscal stress and balanced budget requirements on the funding and measurement of state pension obligations. Journal of Accounting and Public Policy, 21(4-5), 287-313. https://doi.org/10.1016/S0278-4254(02)00064-9

Chiacchio, F., \& Tagliapietra, S. (2018). Italy's pension spending: Implications of an ageing population. Retrieved from https://www.bruegel.org/2018/04/italys-pension-spending-implications-of-an-ageing-population/

Coppini, M. A. (1979). The method of demographic and financial projections on an individual basis and by means of random drawings (MAGIS). Presented at the 7th International Conference of Social Security Actuaries and Statisticians, Acapulco. 
European Commission. (2010). Green Paper, Towards adequate, sustainable and safe European pension systems, COM (2010) 365 final, Brussels.

European Commission. (2018a). The 2018 Ageing Report: Economic and budgetary projections for the 28 EU Member States (2016-2070). European Economy, Institutional Paper no. 079.

European Commission. (2018b). Pension Adequacy Report 2018. Current and Future Income Adequacy in Old Age in the EU. Vol. 2 - Country profiles. Publications Office of the European Union, Luxembourg.

European Economic and Social Committee. (2010). Proposal for a Council Decision on guidelines for the employment policies of the Member States - Part II of the Europe 2020 Integrated Guidelines. COM (2010) 193 final. Reporteur - general: Wolfgang Greif. Brussels.

Franco, D. (2001). Italy: The Search for a Sustainable PAYG Pension System. Presented at the International Seminar on Pensions, Sano-shoin, Hitotsubashi University, Tokyo, Japan.

Geroldi, G. (2014). Le riforme del sistema previdenziale italiano. Retrieved from https://www.academia.edu/7820744/Le_riforme_del_sistema_previdenziale_italiano

Giunta, F., \& Pisani, M. (2020). Il bilancio. Rome, Maggioli.

Guardiancich, I., \& Natali, D. (2018). Pensions in Italy: New challenges and old Problems. Politiche Sociali, 5(3), 437-442. https://doi.org/10.7389/91921

Hinz, R., Heinz, R., Antolin, P., \& Yermo, J. (2010). Evaluating the Financial Performance of Pension Funds, Directions in Development - Finance. The World Bank. https://doi.org/10.1596/978-0-8213-8159-5

Kaifala, G. B., Paisey, C., \& Paisey, N. J. (2019). The UK pensions landscape - A critique of the role of accountants and accounting technologies in the treatment of social and societal risks. Critical Perspectives on Accounting. https://doi.org/10.1016/j.cpa.2019.06.005

Kalyta, P., \& Magnan, M. (2008). Executive pensions, disclosure quality, and rent extraction. Journal of Accounting and Public Policy, 27(2), 133-166. https://doi.org/10.1016/j.jaccpubpol.2008.01.002

Kemp, M. H. D., \& Patel, C. C. (2012). Entity-wide risk management for pension funds. British Actuarial Journal, 17(2), 331-394. https://doi.org/10.1017/S1357321712000086

Marcello, R., \& Lucido, N. (2019). Le passività potenziali: valutazione ed iscrizione in bilancio | Fondazione Nazionale di Ricerca dei Commercialisti.

Mazzola, P., Rimoldi, S. M. L., Rossi, P., Noale, M., Rea, F., Facchini, C.,... Annoni, G. (2016). Aging in Italy: The need for new welfare strategies in an old country. Gerontologist, 56(3), 383-390. https://doi.org/10.1093/geront/gnv152

Morrone, C., \& Angrisani, M. (in press). What about the Information Capacity of the Financial Statement of Pension Funds Established as per Legislative Decree No. 509/94? Economia e Lavoro.

Olivieri, G., Fersini, P., Melisi, G., \& Brusco, L. (2015). Il debito previdenziale pregresso delle Casse privatizzate. News Casse, 3, 15-18.

PwC. (2017). The new financial statements. A summary of revised Italian accounting standards. Retrieved from https://www.pwc.com/it/en/publications/assets/docs/new-financial-statements.pdf

Quagli, A. (2017). Bilancio di esercizio e principi contabili. Turin, Giappichelli.

Quagli, A. (2004). Comunicare il futuro: l'informativa economico-finanziaria di tipo previsionale delle società quotate italiane. Milan, FrancoAngeli.

Reiter, S. A., \& Omer, T. (1992). A critical perspective on pension accounting, pension research and pension terminations. Critical Perspectives on Accounting, 3(1), 61-85. https://doi.org/10.1016/1045-2354(92)90015-J

Rosa, P. (2012). Il debito previdenziale: nozione, misurazione e conseguenze de iure condendo. Diritto e Giustizia, Il quotidiano di informazione giuridica. Retrieved from http://www.dirittoegiustizia.it/news/12/0000055566/Il_debito_previdenziale_nozione_misurazione_e_conse guenze_de_iure_condendo.html

Schipper, K., \& Trombetta, M. (2010). Measurement issues in financial reporting. European Accounting Review 19(3), 425-428. https://doi.org/10.1080/09638180.2010.506282

Selling, T. I., \& Stickney, C. P. (1986). Accounting measures of unfunded pension liabilities and the expected 
present value of future pension cash flows. Journal of Accounting and Public Policy, 5(4), 267-285. https://doi.org/10.1016/0278-4254(86)90023-2

Technical Scientific Committee of Itinerari Previdenziali. (2015). II REPORT 2015 The Italian pension system. Financial and demographic trends of pensions and welfare. Retrieved from https://www.itinerariprevidenziali.it/eventi/archivio-eventi/eventi-2015/34422IIREPORT2015-imp.pdf

Tomassetti, A. (1973). Sulle valutazioni attuariali dei salari e degli oneri annui con estrazione a sorte per il passaggio di stato degli assicurati e pensionati, Quaderno n. 31 dell'istituto di Scienze Attuariali dell'Università degli Studi di Roma La Sapienza.

Vermeer, T. E., Styles, A. K., \& Patton, T. K. (2012). Do local governments present required disclosures for defined benefit pension plans? Journal of Accounting and Public Policy, 31(1), 44-68. https://doi.org/10.1016/j.jaccpubpol.2011.04.002

\section{Notes}

Note 1. A PBO is the present value of retirement benefits already earned by professionals, but not yet paid out (Andrietti, 1995). The amount of this obligation is usually determined by an actuary, based on multiple assumptions.

Note 2. The reference period for calculating it has changed with reforms: it could refer to last paycheck such as the average of the last five/ten earning years.

Note 3. SR is the ratio between the first pension benefit and the last income earned by the professional.

Note 4. For example, with regard to the Italian basic pension, the amount of contributions is capitalized at a five-year moving average of GDP growth.

Note 5. The article 2 of D.M. 29 November 2017 states that the technical budget must be issued also when changes of statutory/regulatory have significant consequences on the evolution of the economic and financial management of the entity.

Note 6 . The entities are required to verify annually that the results of the final balance sheet are in line with the technical-financial ones (art. 6, co. 4 D.M. 29 November 2007).

\section{Copyrights}

Copyright for this article is retained by the author(s), with first publication rights granted to the journal.

This is an open-access article distributed under the terms and conditions of the Creative Commons Attribution license (http://creativecommons.org/licenses/by/4.0/). 